\title{
Potensi Penyimpangan Hukum Dalam Peraturan Pemerintah Pengganti Undang-Undang Nomor 1 Tahun 2020
}

\author{
Ahmad Gelora Mahardika \\ Hukum Tata Negara Institut Agama Islam Negeri Tulungagung \\ Jln. Major Sujadi Timur No. 46 Tulungagung \\ geloradika@gmail.com
}

Received: 19 April 2020; Accepted: 12 Juni 2020; Published: 25 Agustus 2020

DOI: 10.20885/iustum.vol27.iss2.art3

\begin{abstract}
The development of the Corona Virus Disease-2019 (Covid-2019) was followed-up by the Government by issuing a Government Regulation in lieu of Law Number 1 of 2020 (Perpu Number 1 of 2020). The formulation of the problem to be answered in this research is what is the potential for legal irregularities in Government Regulation in lieu of Law Number 1 Year 2020? The research method used is normative juridical with a statutory approach. The results show that there is a potential for legal irregularities in this Perpu. The deviation in the form of a Perppu contradicts a number of Articles in the Legislation. These violations have the potential to give rise to legal uncertainty, because the Perpu is only temporary, namely until the completion of the Covid-19 pandemic outbreak phenomenon which cannot be ascertained when it will end. On the other hand, this Perpu provides enormous powers for a number of officials to take preventive measures that do not correlate directly with the Covid-19 pandemic problem, one of which is liquidity assistance to banks that are both systemically and non-systemically affected. In addition, all officials are given the right to immunity not to be prosecuted both criminal and civil and the decisions issued are not the object of the PTUN dispute, meaning that there is no checks and balances mechanism in the government. Thus, the suggestion given is to revise this Perpu.
\end{abstract}

Key Words: Pandemic; government; law

Abstrak

Berkembangnya Corona Virus Disease-2019 (Covid-2019) ditinjaklanjuti oleh Pemerintah dengan mengeluarkan Peraturan Pemerintah Pengganti Undang-Undang Nomor 1 Tahun 2020 (Perpu Nomor 1 Tahun 2020). Rumusan masalah yang hendak dijawab dalam penelitian ini adalah bagaimanakah potensi penyimpangan hukum dalam Peraturan Pemerintah Pengganti Undang-Undang Nomor 1 Tahun 2020?. Metode penelitian yang digunakan adalah yuridis normatif dengan pendekatan perundangundangan. Hasil penelitian menyimpulkan terdapat potensi penyimpangan hukum dalam Perpu ini. Penyimpangan berupa Perppu tersebut bertentangan dengan sejumlah Pasal dalam Peraturan Perundang-undangan. Pelanggaran tersebut berpotensi melahirkan ketidakpastian hukum, karena Perpu hanya bersifat temporer yaitu hingga selesainya fenomena wabah pandemi Covid-19 yang tidak bisa dipastikan kapan berakhirnya. Di sisi lain, Perpu ini memberikan kekuasaan yang sangat besar bagi sejumlah pejabat untuk melakukan tindakan-tindakan pencegahan yang tidak ada kaitannya secara langsung dengan persoalan pandemi Covid-19, salah satunya adalah bantuan likuiditas kepada Bank yang terdampak baik sistemik maupun tidak sistemik. Selain itu, semua pejabat diberikan hak imunitas untuk tidak dapat dituntut baik secara pidana maupun perdata serta keputusan yang dikeluarkan bukanlah objek sengketa PTUN, dalam artian tidak ada mekanisme checks and balances di dalam pemerintahan. Sehingga, saran yang diberikan adalah dilakukan revisi terhadap Perpu ini.

Kata-kata Kunci: Pandemi; pemerintah; hukum 


\section{Pendahuluan}

Berkembangnya wabah pandemi Corona Virus Diseases 2019 (Covid-19) yang terjadi di Indonesia sejak awal Maret $2020^{1}$ membuat Pemerintah berinisiatif untuk mengambil beberapa langkah strategis di bidang hukum, salah satunya adalah dengan diterbitkannya Peraturan Pemerintah Pengganti Undang-Undang (Perpu) Nomor 1 Tahun 2020 tentang Kebijakan Keuangan Negara dan Stabilitas Sistem Keuangan Untuk Penanganan Pandemi Corona Virus Disease 2019 (Covid19) dan/atau Dalam Rangka Menghadapi Ancaman Yang Membahayakan Perekonomian Nasional dan/atau Stabilitas Sistem Keuangan. Pada dasarnya Perpu tersebut dikeluarkan sebagai upaya Pemerintah untuk mengantisipasi potensi terjadinya krisis moneter diakibatkan wabah pandemi Covid-19, namun pada sejumlah pasal terdapat sejumlah ketentuan yang berpotensi melahirkan penyimpangan. Pada Pasal 27 Perpu tersebut disebutkan bahwa Pejabat yang melakukan tindakan berkaitan dengan Perpu Nomor 1 Tahun 2020 tidak dapat dituntut baik secara pidana/perdata sepanjang dalam melaksanakan tugasnya telah didasarkan pada itikad baik dan peraturan perundang-undangan yang berlaku. Selain itu pada pasal yang sama dikatakan bahwa segala tindakan atau keputusan yang diambil berdasarkan Perpu Nomor 1 Tahun 2020 bukan merupakan objek sengketa Peradilan Tata Usaha Negara. Kedua Pasal ini menjadi perdebatan karena ada potensi lahirnya penyimpangan hukum sebagai implikasi diterapkannya kedua pasal tersebut. ${ }^{2}$

Kasus pandemi Covid-19 menjadi salah satu sorotan publik yang cukup massif. Hal itu disebabkan fenomena Corona merupakan tragedi internasional yang mana terjadi hampir di seluruh negara di penjuru dunia. Oleh karena itulah secara otomatis warga negara Indonesia akan membandingkan penanganan Pemerintah Indonesia dengan pemerintah negara lain terkait tindakan yang dilakukan dalam menangani persoalan wabah tersebut. Pada hakikatnya, Indonesia sudah mempunyai sejumlah regulasi yang mengatur persoalan wabah

\footnotetext{
${ }^{1}$ https://nasional.kompas.com/read/2020/03/03/06314981/fakta-lengkap-kasus-pertama-virus-coronadi-indonesia?page $=$ all diakses pada 14 Mei 2020

2 Pasal 27 Perpu Nomor 1 Tahun 2020 tentang Kebijakan Keuangan Negara dan Stabilitas Sistem Keuangan Untuk Penanganan Pandemi Corona Virus Disease 2019 (Covid-19) dan/atau Dalam Rangka Menghadapi Ancaman Yang Membahayakan Perekonomian Nasional dan/atau Stabilitas Sistem Keuangan
} 
penyakit menular yaitu Undang-Undang Nomor 24 Tahun 2007 tentang Penangulangan Bencana dan Undang-Undang Nomor 6 Tahun 2018 tentang Kekarantinaan Kesehatan. Kedua undang-undang tersebut pada dasarnya sudah cukup untuk menjadi landasan hukum bagi Pemerintah untuk menyelesaikan persoalan pandemi Covid-19. Akan tetapi persoalan yang kemudian muncul adalah ketiadaan anggaran negara yang harus diperlukan bagi Pemerintah untuk menyelesaikan bencana pandemi wabah Covid-19.

Mengacu pada Undang-Undang Dasar Negara Republik Indonesia Tahun 1945 (UUD NRI 1945), Indonesia merupakan negara hukum (rechstaat) atau a state governed by the rule of law ${ }^{3}$, dalam artian seburuk apapun undang-undang ketika peraturan tersebut telah diundangkan, maka pemerintah dan rakyat harus tunduk pada peraturan tersebut. Oleh karena itulah setiap peraturan perundangundangan haruslah dipastikan seminimalisir mungkin terdapat potensi melahirkan tindakan kecurangan (fraud). ${ }^{4}$

Selain meminimalisir tindakan kecurangan, suatu regulasi tidak boleh bertentangan dengan peraturan yang lebih tinggi ataupun bertentangan dengan regulasi yang kedudukannya setara tanpa memberikan kepastian hukum terkait status peraturan tersebut apakah tetap dipertahankan ataukah dinyatakan tidak berlaku lagi. Sebagai sebuah peraturan perundang-undangan, keberadaan Perpu yang setara dengan Undang-Undang mengacu pada hierarki peraturan perundang-undangan sebagaimana yang tercantum pada Pasal 7 ayat (1) Undang-Undang Nomor 12 Tahun 2011 tentang Pembentukan Peraturan Perundang-undangan tentu akan memunculkan persoalan baru di wilayah penegakan hukum manakala ditemukan norma yang saling bertentangan, apalagi dalam aturan peralihan pada Perpu Nomor 1 Tahun 2020 tidak disebutkan secara mendetail terkait status undang-undang yang terkait apakah tetap dipertahankan ataukah dinyatakan tidak berlaku lagi dengan lahirnya Perpu. Oleh karena itulah menjadi kewajaran bilamana timbul kekhawatiran Perpu Nomor 1 Tahun 2020

\footnotetext{
${ }^{3}$ Christian Boulanger, "Constitutionalism in East Central Europe? The Case of Slovakia under Meciar", East European Quarterly Vol. 33, No. 1, 1999, hlm. 21-50.

${ }^{4}$ Kent Greenfield, "The Unjustified Absence of Federal Fraud Protection in the Labor Market", Yale Law Journal Vol. 107, No. 3, 1997, hlm. 715-788.
} 
akan berpotensi melahirkan sejumlah penumpang gelap (free riders) untuk memanfaatkan Perpu tersebut demi kepentingan pribadi atau golongan tertentu.

\section{Rumusan Masalah}

Beradasarkan latar belakang masalah di atas, penelitian ini hendak menjawab pertanyaan terkait bagaimanakah kemungkinan timbulnya tindakan penyimpangan setelah lahirnya Peraturan Pemerintah Pengganti UndangUndang Nomor 1 Tahun 2020 yang telah disepakati menjadi Undang-Undang Nomor 2 Tahun 2020?

\section{Tujuan Penelitian}

Berdasarkan rumusan masalah sebagaimana yang tercantum di atas, tujuan penelitian ini adalah untuk mengetahui potensi penyimpangan hukum dalam penerbitan Peraturan Pemerintah Pengganti Undang-Undang Nomor 1 Tahun 2020.

\section{Metode Penelitian}

Penelitian dilakukan melalui penelitian hukum normatif, dengan mengkaji dan menganalisis peraturan perundang-undangan atau bahan hukum lain yang berkaitan dengan Potensi Penyimpangan Hukum Dalam Peraturan Pemerintah Pengganti Undang-Undang Nomor 1 Tahun 2020. Penelitian hukum ini dilakukan melalui pendekatan peraturan perundang-undangan (statutory approach). ${ }^{5}$ Pendekatan peraturan perundang-undangan dilakukan dengan mengkaji peraturan perundang-undangan yang terkait dengan tema penelitian.

Penelitian hukum normatif ini menggunakan jenis data sekunder atau data yang diperoleh melalui bahan kepustakaan, sehingga metode pengumpulan data dilaksanakan dengan mencari pustaka yang relevan, baik melalui perpustakaan maupun pusat data jurnal daring. Pengumpulan data sekunder yang digunakan dalam penelitian ini difokuskan pada: (a) bahan hukum primer, berupa peraturan perundang-undangan yang terkait dengan tema penelitian; dan (b) bahan hukum sekunder, berupa buku referensi dan jurnal yang terkait dengan tema penelitian

${ }^{5}$ Johni Ibrahim, Teori Dan Metodologi Penelitian Hukum Normatif, Bayumedia Publishing, Malang, 2007, hlm. 
dan menguraikan lebih lanjut bahan hukum primer dalam konteks teoretis dan implementasi yang relevan.

\section{Hasil Penelitian dan Pembahasan}

Fenomena Pandemi Covid-19 yang terjadi secara global berdampak pula terhadap Indonesia. Pemerintah sebagai pelaksana undang-undang telah mengambil sejumlah tindakan sebagai upaya untuk mengatasi wabah pandemi Covid-19, salah satunya adalah menunjuk Badan Nasional Penanggulangan Bencana (BNPB) sebagai leading sector untuk menangani persoalan Covid-19. ${ }^{6}$ Penunjukan BPNP didasarkan pada Undang-Undang Nomor 24 Tahun 2007 yang dalam ketentuan umum disebutkan bahwa selain bencana alam, pemerintah bisa menetapkan bencana non-alam sebagai bagian dari bencana nasional, bencana non-alam merupakan bencana yang diakibatkan oleh peristiwa atau rangkaian peristiwa non-alam yang antara lain berupa gagal teknologi, gagal modernisasi, epidemi, dan wabah penyakit.

Keputusan Pemerintah untuk mengkategorikan pandemi Covid-19 sebagai bencana non-alam secara tidak langsung sebagai upaya Presiden untuk menyatakan bahwa pandemi Covid-19 merupakan bencana nasional sebagaimana diatur dalam Pasal 7 Undang-Undang Nomor 24 Tahun 2007. Selain penetapan status bencana nasional, pemerintah juga menggunakan Undang-Undang Nomor 6 Tahun 2018 tentang Kekarantinaan Kesehatan untuk menyelesaikan fenomena pandemi Covid-19. Akan tetapi sejumlah Pasal yang tercantum dalam undangundang tersebut berpotensi untuk mengeluarkan biaya yang cukup besar yang mana ada potensi ketidakmampuan negara dalam memenuhi tanggung jawab tersebut, salah satunya adalah ketentuan pada Pasal 55 ayat (1) yang menyatakan bahwa selama dalam Karantina Wilayah, kebutuhan hidup dasar orang dan makanan hewan ternak yang berada di wilayah karantina menjadi tanggung jawab Pemerintah Pusat.

Pada hakikatnya, UUD NRI 1945 memberikan dua alternatif sikap Presiden manakala terjadi kondisi sebagaimana yang dimaksud diatas, yaitu tercantum pada Pasal 12 UUD NRI terkait kondisi bahaya serta Pasal 22 UUD NRI 1945

${ }^{6}$ https://news.detik.com/berita/d-4938296/dipimpin-kepala-bnpb-ini-gambaran-kerja-tim-penangananvirus-corona diakses pada tanggal 14 Mei 2020 
terkait kegentingan yang memaksa. Mengacu pada pendapat S.E Finer, yang membedakan keadaan darurat dalam tiga kategori, yaitu: ${ }^{7}$ Pertama, keadaan darurat karena perang (state of war); Kedua, keadaan darurat karena ketegangan (state of tension) termasuk dalam bencana alam atau ketegangan sosial karena konflik; Ketiga, keadaan darurat karena kepentingan internal pemerintahan yang memaksa (innere notstand). Meskipun tidak terdapat keadaan darurat, tetapi ada kepentingan internal pemerintahan yang mesti dilakukan tetapi instrumen undang-undang yang ada tidak memungkinkan untuk itu.

Berdasarkan Venice Commision sebuah forum Uni Eropa yang terdiri dari pakar hukum tata negara, "state of tension" covers the conditions that precede a state of defence, such as a "situation approaching civil war or preparation for international war". "Internal state of emergency" covers natural disasters, grave accidents, threats to the free democratic order in the federation or the Länder, or dangers to public security or order. ${ }^{8}$ Bilamana melihat klasifikasi yang disampaikan S.E Finer, maka wabah pandemi Covid-19 termasuk dalam kategori state of tension yang mana satu-satunya regulasi yang mengatur hal tersebut dalam sistem hukum Indonesia adalah Peraturan Pemerintah Pengganti Undang-Undang Nomor 23 Tahun 1959 tentang Pencabutan Undang-Undang No. 74 Tahun 1957 dan Menetapkan Keadaan Bahaya yang didalamnya mengatur terkait darurat sipil dan darurat militer. Akan tetapi opsi tersebut tidak diambil Presiden, Presiden justru memutuskan untuk mengeluarkan Perpu yang mana menurut Putusan MK Nomor 138/PUUVII/2009 dapat diterbitkan oleh Presiden selama memenuhi tiga persyaratan yaitu: 1) adanya kebutuhan mendesak kebutuhan untuk menyelesaikan masalah hukum dengan cepat menggunakan undang-undang, 2) undang-undang yang dibutuhkan tersebut belum ada sehingga terjadi kekosongan hukum atau undang-undang sudah ada namun belum memadai, 3) kekosongan hukum tersebut tidak dapat diatasi dengan cara membuat UU secara prosedur biasa karena akan memerlukan waktu yang cukup lama sedangkan keadaan yang mendesak tersebut perlu kepastian untuk diselesaikan.

\footnotetext{
${ }^{7}$ Jimy Asshiddiqie, Pokok-Pokok Hukum Tata Negara Indonesia Pasca Reformasi, PT Bhuana Ilmu Populer, Jakarta, 2007, hlm. 356.

${ }^{8}$ https://www.venice.coe.int/webforms/documents/default.aspx?pdffile=CDL-STD(1995)012-e diakses pada tanggal 20 Mei 2020
} 
Terlihat dalam Putusan MK tersebut, Perpu merupakan produk hukum yang dikeluarkan Presiden dalam kondisi normal bukan dalam kondisi bahaya sebagaimana yang diatur dalam Pasal 12 UUD NRI 1945, dalam artian Perpu tersebut tetaplah dianggap produk hukum normal yang tidak boleh bertentangan dengan konstitusi serta undang-undang terkait sepanjang aturan tersebut belum atau tidak dibatalkan oleh Perpu. Selain itu, dalam kondisi normal, maka segala tindakan Pemerintah selayaknya tetap harus tunduk pada prinsip negara hukum yaitu equality before the law yaitu semua sama didepan hukum.

Sikap Presiden untuk tidak menetapkan status bahaya berimplikasi terhadap tetap berlakunya prinsip-prinsip negara hukum (rechstaat) yaitu pemerintahan berdasarkan peraturan-peraturan (wetmatigheid van bestuur). ${ }^{9}$ Namun tindakan Presiden untuk tidak menetapkan status bahaya, berdampak lurus terhadap semakin meluasnya wabah pandemi covid-19. Salah satu sektor yang terdampak adalah aspek ekonomi, ${ }^{10}$ sebagai contoh penutupan perusahaan, pemberhentian tenaga kerja, penutupan tempat wisata, hingga sejumlah aspek lainnya yang membuat Pemerintah berada dalam titik nadir tersulit pada sektor ekonomi. Dalam kondisi pelik, menjadi sebuah hal yang lumrah manakala Pemerintah berusaha menggeser anggaran yang tercantum dalam APBN untuk dialokasikan dalam penanganan Covid-19. Bersumber pada hal tersebutlah Presiden kemudian mengeluarkan Peraturan Pemerintah Pengganti UndangUndang Nomor 1 Tahun 2020 tentang Kebijakan Keuangan Negara dan Stabilitas Sistem Keuangan Untuk Penanganan Pandemi Corona Virus Disease 2019 (Covid19) dan/atau Dalam Rangka Menghadapi Ancaman Yang Membahayakan Perekonomian Nasional dan/atau Stabilitas Sistem Keuangan, yang dalam pokok isinya memberikan kewenangan bagi Pemerintah untuk melakukan revisi anggaran tanpa keterlibatan DPR.

Pergeseran kewenangan tersebut tentu saja berpotensi melanggar Pasal 23 UUD NRI 1945 yang berbunyi sebagai berikut:

9 Zahermann Armandz Muabezi, "Negara Berdasarkan Hukum (Rechtsstaats) Bukan Kekuasaan (Machtsstaat)", Jurnal Hukum Dan Peradilan, Vol. 6, No. 3, 2017, hlm. 421.

10 Colin C. Williams and Aysegul Kayaoglu, "The Coronavirus Pandemic and Europe's Undeclared Economy: Impacts And A Policy Proposal", South East European Journal of Economics and Business, Vol. 15, No. 1, 2020, hlm. 80-92. 


\section{Pasal 23}

(1)Anggaran pendapatan dan belanja negara sebagai wujud dari pengelolaan keuangan negara ditetapkan setiap tahun dengan undang-undang dan dilaksanakan secara terbuka dan bertanggung jawab untuk sebesarbesarnya kemakmuran rakyat.

(2)Rancangan undang-undang anggaran pendapatan dan belanja negara diajukan oleh Presiden untuk dibahas bersama Dewan Perwakilan Rakyat dengan memperhatikan pertimbangan Dewan Perwakilan Daerah.

(3)Apabila Dewan Perwakilan Rakyat tidak menyetujui rancangan anggaran pendapatan dan belanja negara yang diusulkan oleh Presiden, Pemerintah menjalankan Anggaran Pendapatan dan Belanja Negara tahun yang lalu.

Jika mengacu pada ketentuan Pasal 23 UUD NRI 1945 di atas, maka Pasal 12 ayat (2) Perpu Nomor 1 Tahun 2020 jelas bertentangan dengan UUD 1945 Pasal 12 yang berbunyi sebagai berikut:

(1)Pelaksanaan kebijakan keuangan negara dan langkah-langkah sebagaimana dimaksud dalam Pasal 2 sampai dengan Pasal 11 dilakukan dengan tetap memperhatikan tata kelola yang baik.

(2)Perubahan postur dan/atau rincian Anggaran Pendapatan dan Belanja Negara (APBN) dalam rangka pelaksanaan kebijakan keuangan negara dan langkah-langkah sebagaimana dimaksud dalam Pasal 2 sampai dengan Pasal 11 diatur dengan atau berdasarkan Peraturan Presiden.

Ketentuan pada Pasal 12 Perpu Nomor 1 Tahun 2020 secara jelas bertentangan dengan Pasal 23 UUD NRI 1945, pertentangan tersebut terkait dengan peniadaan fungsi budgeting DPR RI baik dalam proses pembentukan APBN maupun produk hukum pengaturannya.

Tabel 1

Pasal 12 Perpu Nomor 1 Tahun 2020 dan Pasal 23 UUD 1945 Terkait Perubahan APBN

\begin{tabular}{ccc}
\hline Tahapan & Pasal 12 Perpu Nomor 1 & Pasal 23 UUD 1945 \\
\hline $\begin{array}{c}\text { Proses Pembentukan } \\
\text { Pengaturannya }\end{array}$ & Pemerintah & Pemerintah dan DPR \\
Peraturan Presiden & Undang-Undang \\
\hline
\end{tabular}

Sumber : diolah dari berbagai sumber

Peniadaan kewenangan DPR dalam pembahasan anggaran berpotensi menghilangkan aspek pengawasan dalam pengelolaan anggaran, karena meskipun DPR telah menyetujui Perpu Nomor 1 Tahun 2020 menjadi UndangUndang Nomor 2 Tahun 2020 akan tetapi hal tersebut tidak sejalan dengan Pasal 23 UUD NRI 1945 yang mana perlunya persetujuan DPR terkait pembahasan 
APBN adalah sebagai upaya pemenuhan checks and balances dalam konsep pemisahan kekuasaan antara eksekutif dan legislatif. Selain itu, fungsi anggaran merupakan salah satu fungsi yang esensial dalam konstitusi. Hal tersebut sejalan dengan pendapat Price yang menyatakan, bahwa Congress's "power of the purse" its authority to deny access to public funds - is one of its most essential constitutional authorities. ${ }^{11}$ Peniadaan kewenangan DPR dalam pengawasan anggaran secara tidak langsung berpotensi untuk memunculkan penyimpangan yang dilakukan oleh Pemerintah karena ditiadakannya pengawasan.

\section{Hak Imunitas Pejabat dalam Perpu}

Selain peniadaan kewenangan DPR untuk melakukan pembahasan dan persetujuan perubahan APBN, Perpu Nomor 1 Tahun 2020 juga mempunyai persoalan lain yaitu terkait pasal yang mengatur hak imunitas pejabat negara. Ketentuan tersebut diatur dalam Ketentuan Penutup Pasal 27 yang berbunyi sebagai berikut:

\section{BAB V \\ KETENTUAN PENUTUP}

Pasal 27

(1)Biaya yang telah dikeluarkan Pemerintah dan/atau lembaga anggota KSSK dalam rangka pelaksanaan kebijakan pendapatan negara termasuk kebijakan di bidang perpajakan, kebijakan belanja negara termasuk kebijakan di bidang keuangan daerah, kebijakan pembiayaan, kebijakan stabilitas sistem keuangan, dan program pemulihan ekonomi nasional, merupakan bagian dari biaya ekonomi untuk penyelamatan perekonomian dari krisis dan bukan merupakan kerugian negara.

(2)Anggota KSSK, Sekretaris KSSK, anggota sekretariat KSSK, dan pejabat atau pegawai Kementerian Keuangan, Bank Indonesia, Otoritas Jasa Keuangan, serta Lembaga Penjamin Simpanan, dan pejabat lainnya, yang berkaitan dengan pelaksanaan Peraturan Pemerintah Pengganti UndangUndang ini, tidak dapat dituntut baik secara perdata maupun pidana jika dalam melaksanakan tugas didasarkan pada iktikad baik dan sesuai dengan ketentuan peraturan perundang-undangan.

(3)Segala tindakan termasuk keputusan yang diambil berdasarkan Peraturan Pemerintah Pengganti Undang-Undang ini bukan merupakan objek gugatan yang dapat diajukan kepada peradilan tata usaha negara.

11 Zachary S. Price, "Funding Restrictions and Separation of Powers", Vanderbilt Law Review, Vol. 71, No. 2, 2018, hlm. 357-464. 
Berdasarkan ketentuan pada Pasal 27 Perpu Nomor 1 Tahun 2020 di atas, terdapat beberapa poin yang bisa disimpulkan, yaitu:

1. Biaya apapun yang dikeluarkan oleh Pemerintah selama wabah bukan termasuk kerugian negara.

2. Pejabat tidak bisa dituntut baik secara perdata maupun pidana jika dalam melaksanakan tugas didasarkan pada iktikad baik dan sesuai dengan ketentuan peraturan perundang-undangan.

3. Tindakan yang dilakukan oleh Pejabat yang didasarkan pada Perpu bukan objek sengketa PTUN.

Terkait adanya tiga hal tersebut, selama diberlakukannya Perpu Nomor 1 Tahun 2020 maka Pejabat Pemerintahan akan memperoleh kekebalan hukum (imunitas). Ketiga hak imunitas tersebut pada hakikatnya melanggar sejumlah ketentuan baik yang tercantum dalam Undang-Undang Dasar 1945 maupun Undang-Undang. Meskipun dalam Undang-Undang Nomor 30 Tahun 2014 tentang Administrasi Pemerintahan dikenal konsep diskresi, akan tetapi Pasal 24 huruf $b$ undang-undang tersebut telah memberikan syarat pelaksanaan diskresi, yaitu tidak bertentangan dengan ketentuan peraturan perundang-undangan. Berdasarkan hal tersebut, Penulis dapat merinci berikut adalah sejumlah peraturan perundang-undangan yang telah dilanggar oleh ketentuan pada Perpu Nomor 1 Tahun 2020:

\section{Pasal 1 ayat (3) Undang-Undang Dasar Negara Republik Indonesia 1945}

Pasal 1 ayat (3) UUD NRI 1945 secara jelas menyatakan bahwa Indonesia merupakan negara hukum, dalam artian prinsip-prinsip negara hukum melekat dalam sistem hukum Indonesia. Menurut Jimly Asshidiqie, ada dua belas ciri penting dari negara hukum, yaitu; 12
a. supremasi hukum,
b. persamaan dalam hukum,
c. asas legalitas,
d. pembatasan kekuasaan,
e. organ eksekutif yang independen,
f. peradilan bebas dan tidak memihak,
g. peradilan tata usaha negara,

${ }^{12}$ Jimly Asshiddiqie, Konstitusi Dan Konstitusionalisme Indonesia, Konstitusi Press, Jakarta, 2005, hlm. 15. 
h. peradilan tata negara,

i. perlindungan hak asasi manusia,

j. bersifat demokratis,

k. sarana untuk mewujudkan tujuan negara, dan

1. transparansi dan kontrol sosial.

Berdasarkan hal tersebut di atas, Perpu Nomor 1 Tahun 2020 telah melanggar sejumlah ciri mendasar negara hukum, yaitu persamaan dalam hukum, pembatasan kekuasaan, peradilan tata usaha negara, dan perlindungan Hak Asasi Manusia. Terkait dengan persamaan dalam hukum (equality before the law), pada dasarnya tidak ada perbedaan antara pejabat satu dengan yang lainnya ataupun dengan rakyat biasa terkait pelanggaran hukum pidana maupun perdata, sementara itu pada Pasal 27 Perpu Nomor 1 Tahun 2020 terdapat beberapa jabatan yang tidak bisa dituntut baik secara pidana maupun perdata terkait kebijakannya yang didasarkan pada Perpu Nomor 1 Tahun 2020 yaitu:

1) Anggota Komite Stabilitas Sistem Keuangan (KSSK)

2) Sekretaris KSSK,

3) Anggota sekretariat KSSK, dan

4) Pejabat atau pegawai Kementerian Keuangan, Bank Indonesia, Otoritas Jasa Keuangan, serta Lembaga Penjamin Simpanan, dan

5) Pejabat lainnya yang berkaitan dengan pelaksanaan Perpu Nomor 1 Tahun 2020.

Pertanyaan yang kemudian muncul adalah apakah lima kelompok pejabat tersebut di atas akan memperoleh hak imunitas dengan terbitnya Perpu Nomor 1 Tahun 2020? Sedangkan setiap kebijakan yang berpotensi merugikan negara tidak mengenal pengecualian, siapapun yang bersalah harus dihukum sesuai dengan peraturan perundang-undangan yang berlaku. Hal tersebut merupakan konsep dasar negara hukum.

\section{Pasal 28D ayat (1) Undang-Undang Dasar Negara Republik Indonesia 1945}

Pasal 28D ayat (1) UUD NRI 1945 menyatakan bahwa setiap orang berhak atas perlakuan yang sama dihadapan hukum. Dalam artian hukum harus memperlakukan setiap orang dengan cara dan metode yang sama. Hal itu ditegaskan oleh Frej Klem Thomsen, yang menyatakan bahwa the principle of equality before the law is a principle of procedural legal equality will hold that a court 
ought to treat a case in a certain way if similar cases have been treated that way before. ${ }^{13}$ Hal tersebut kemudian ditegaskan oleh Wallerstein yang menyatakan bahwa hal mendasar dalam kesetaraan adalah hak yang sama the fundamental social equality of all individuals endowed with equal rights. ${ }^{14}$

Apabila melihat Perpu Nomor 1 Tahun 2020, terdapat pelanggaran hak asasi atas kesetaraan didepan hukum (equality before the law). Kesetaraan tersebut bukan hanya antara pemerintah dan rakyat semata, akan tetapi juga terjadi di internal pejabat pemerintahan. Penulis dapat klasifikasikan ketidaksetaraan tersebut menjadi tabel sebagai berikut:

Tabel 2

Perlakuan yang Berbeda pada Pejabat Perpu Nomor 1 Tahun 2020

\begin{tabular}{lcc}
\hline \multicolumn{1}{c}{ Tindakan } & \multicolumn{2}{c}{ Pejabat yang tercantum } \\
\cline { 2 - 3 } & di luar Perpu & di Perpu \\
\hline $\begin{array}{l}\text { Melakukan kebijakan di bidang perpajakan yang } \\
\text { merugikan keuangan negara }\end{array}$ & Pidana & Bukan Pidana \\
$\begin{array}{l}\text { Melakukan kebijakan belanja negara termasuk } \\
\text { kebijakan di bidang keuangan daerah yang } \\
\text { merugikan keuangan negara }\end{array}$ & Pidana & Bukan Pidana \\
$\begin{array}{l}\text { Melakukan kebijakan pembiayan yang } \\
\text { merugikan keuangan negara }\end{array}$ & Pidana & Bukan Pidana \\
$\begin{array}{l}\text { Melakukan kebijakan stabilitas sistem keuangan } \\
\text { yang merugikan keuangan negara }\end{array}$ & Pidana & Bukan Pidana \\
$\begin{array}{l}\text { Melakukan program pemulihan ekonomi } \\
\text { nasional yang merugikan keuangan negara }\end{array}$ & Pidana & Bukan Pidana \\
\hline
\end{tabular}

Meskipun dalam daftar kebijakan yang tercantum pada tabel 2 hampir dipastikan bahwa hanya pejabat tertentu yang mempunyai kewenangan, akan tetapi bagaimana dengan Pejabat lain yang secara tidak langsung berkaitan dengan Covid-19, akan tetapi mempunyai kebijakan yang terkait dengan daftar kebijakan pada tabel 2?. Apakah akan dikenakan sanksi pidana ataukah tidak?, begitupula dengan BUMN dan BUMD hingga pelaksana pemerintahan lainnya di tingkat desa. Norma dalam Perpu Nomor 1 Tahun 2020 selain menghadirkan

\footnotetext{
${ }^{13}$ Frej Klem Thomsen, "Concept, Principle, and Norm-Equality before the Law Reconsidered", Legal Theory Vol. 24, No. 2, 2018, hlm. 103-134.

${ }^{14}$ Immanuel Wallerstein, "Citizens All? Citizens Some! The Making of the Citizen”, Comparative Studies in Society and History Vol. 45, No. 04, 2003, hlm. 650-680.
} 
potensi pelanggaran asas negara hukum, juga berpotensi melahirkan perlakuan berbeda di depan hukum (inequality before the law).

\section{Pasal 2 dan 3 Undang-Undang Nomor 31 Tahun 1999 juncto Undang-Undang Nomor 20 Tahun 2001 tentang Pemberantasan Tindak Pidana Korupsi}

Selain adanya potensi pelanggaran terhadap UUD NRI 1945, Perpu Nomor 1 Tahun 2020 juga berpotensi menciptakan kompleksitas penegakan hukum tindak pidana korupsi sebagaimana yang tercantum dalam Pasal 2 dan 3 UndangUndang tentang Pemberantasan Tindak Pidana Korupsi. Berdasarkan Pasal 2 dan 3 Undang-Undang Nomor 31 Tahun 1999 juncto Undang-Undang Nomor 20 Tahun 2001 Tentang Pemberantasan Tindak Pidana Korupsi disebutkan bahwa:

\section{Pasal 2}

(1)Setiap orang yang secara melawan hukum melakukan perbuatan memperkaya diri sendiri atau orang lain atau suatu korporasi yang dapat merugikan keuangan negara atau perekonomian negara, dipidana penjara dengan penjara seumur hidup atau pidana penjara paling singkat 4 (empat) tahun dan paling lama 20 (dua puluh) tahun dan denda paling sedikit Rp. 200.000.000,00 (dua ratus juta rupiah) dan paling banyak Rp. 1.000.000.000,00 (satu milyar rupiah).

(2)Dalam hal tindak pidana korupsi sebagaimana dimaksud dalam ayat (1) dilakukan dalam keadaan tertentu, pidana mati dapat dijatuhkan.

\section{Pasal 3}

Setiap orang yang dengan tujuan menguntungkan diri sendiri atau orang lain atau suatu korporasi, menyalahgunakan kewenangan, kesempatan atau sarana yang ada padanya karena jabatan atau kedudukan yang dapat merugikan keuangan negara atau perekonomian negara, dipidana dengan pidana penjara seumur hidup atau pidana penjara paling singkat 1 (satu) tahun dan paling lama 20 (dua puluh) tahun dan atau denda paling sedikit Rp. 50.000.000,00 (lima puluh juta rupiah) dan paling banyak Rp. 1.000.000.000,00 (satu milyar rupiah).

Definisi setiap orang dalam Undang-Undang tersebut diatas mengacu pada teori dasar ilmu perundang-undangan kata "setiap orang" bermakna bahwa ketentuan pidana dalam pasal tersebut berlaku bagi siapapun tanpa pengecualian. Oleh karena itulah, pejabat yang tercantum dalam Perpu Nomor 1 Tahun 2020 yang dianggap merugikan uang negara selayaknya juga harus dituntut secara pidana berdasarkan Pasal 3 undang-undang tentang Pemberantasan Tindak Pidana Korupsi yaitu dituntut dengan pidana penjara 
seumur hidup atau pidana penjara paling singkat 1 tahun dan paling lama 20 tahun dan atau denda paling sedikit Rp. 50.000.000,00 dan paling banyak Rp. 1.000.000.000,00.

Selain potensi adanya pelanggaran terhadap kerugian negara, salah satu tindakan yang dianggap memperkaya korporasi sebagaimana yang tercantum pada Pasal 2 Undang-Undang tentang Pemberantasan Tindak Pidana Korupsi juga terdapat pada 16 ayat (1) Perpu Nomor 1 Tahun 2020 yang berbunyi sebagai berikut:

\section{Pasal 16}

(1)Untuk mendukung pelaksanaan kewenangan KSSK dalam rangka penanganan permasalahan stabilitas sistem keuangan sebagaimana dimaksud dalam Pasal 15 ayat (1), Bank Indonesia diberikan kewenangan untuk:

a. memberikan pinjaman likuiditas jangka pendek atau pembiayaan likuiditas jangka pendek berdasarkan prinsip syariah kepada Bank Sistemik atau bank selain Bank Sistemik;

b. memberikan Pinjaman Likuiditas Khusus kepada Bank Sistemik yang mengalami kesulitan likuiditas dan tidak memenuhi persyaratan pemberian pinjaman likuiditas jangka pendek atau pembiayaan likuiditas jangka pendek berdasarkan prinsip syariah yang dijamin oleh Pemerintah dan diberikan berdasarkan Keputusan KSSK;

c. membeli Surat Utang Negara dan/atau Surat Berharga Syariah Negara berjangka panjang di pasar perdana untuk penanganan permasalahan sistem keuangan yang membahayakan perekonomian nasional, termasuk Surat Utang Negara danf atau Surat Berharga Syariah Negara yang diterbitkan dengan tujuan tertentu khususnya dalam rangka pandemi Corona Virus Disease 2019 (covid-19);

d. membeli/repo surat berharga negara yang dimiliki Lembaga Penjamin Simpanan untuk biaya penanganan permasalahan solvabilitas Bank Sistemik dan bank selain Bank Sistemik;

e. mengatur kewajiban penerimaan dan penggunaan devisa bagi penduduk termasuk ketentuan mengenai penyerahan, repatriasi, dan konversi devisa dalam rangka menjaga kestabilan makroekonomi dan sistem keuangan; dan

f. memberikan akses pendanaan kepada korporasi/swasta dengan cara repo Surat Utang Negara atau Surat Berharga Syariah Negara yang dimiliki korporasi/ swasta melalui perbankan.

Tertentang mengacu pada pasal tersebut di atas, terdapat potensi untuk menihilkan pengawasan dari kekuasaan diluar kekuasaan ekeskutif terhadap keputusan pengucuran dana bantuan likuiditas terhadap Bank sistemik maupun 
tidak sistemik. Padahal kasus pencairan dana likuiditas terhadap Bank menyimpan kapasitas penyimpangan yang sangat besar. Sebagai contoh adalah kasus Bantuan Likuiditas Bank Indonesia (BLBI) pada 1998 yang diperkirakan merugikan negara senilai Rp. 138.000.000.000.000,00.15 Selain itu terdapat kasus lain yang terjadi pada 2008 yaitu pemberian dana talangan (bailout) kepada Bank Century yang merugikan negara sebesar Rp. 6.742. 000.000.000,00.16

Berdasarkan kasus-kasus tersebut di atas, pemberian dana likuiditas membuka celah lahirnya pelanggaran tindak pidana korupsi, oleh karena itulah selayaknya bantuan likuiditas diawasi lebih ketat penggunaannya bukan malah diberikan kelonggaran karena hal tersebut berpotensi melahirkan penyimpangan yang serupa untuk ke depannya. Selain itu hingga saat ini, Pemerintah tidak pernah menetapkan status Indonesia dalam kondisi darurat moneter sebagaimana yang terjadi pada 1998 dan 2008, akan tetapi yang yang telah ditetapkan oleh Pemerintah pada 2020 merupakan darurat kesehatan sebagai efek adanya wabah pandemi Covid-19. Sementara itu prinsip dasar pemberian dana likuiditas (bailout) didasarkan pada konsepsi yang disebabkan oleh krisis kekuangan. ${ }^{17}$

Pemerintah secara tegas menyatakan bahwa kondisi yang terjadi sebagai efek pandemi Covid-19 merupakan darurat kesehatan yang berimplikasi pada krisis moneter, maka apabila mengacu pada penjelasan Pasal 2 ayat (2) UndangUndang Nomor Nomor 31 Tahun 1999 juncto Undang-Undang Nomor 20 Tahun 2001 tentang Pemberantasan Tindak Pidana Korupsi yang menyatakan bahwa tindak pidana korupsi apabila dilakukan dalam keadaan tertentu, pidana mati dapat dijatuhkan. Dalam penjelasan pada pasal tersebut disebutkan:

"Yang dimaksud dengan 'keadaan tertentu' dalam ketentuan ini dimaksudkan sebagai pemberatan bagi pelaku tindak pidana korupsi apabila tindak pidana tersebut dilakukan pada waktu negara dalam keadaan bahaya sesuai dengan undang-undang yang berlaku, pada waktu terjadi bencana alam nasional, sebagai pengulangan tindak pidana korupsi, atau pada waktu negara dalam keadaan krisis ekonomi dan moneter".

\footnotetext{
${ }^{15}$ Iswi Hariyani, Restrukturisasi Dan Penghapusan Kredit Macet, Kompas Gramedia, Jakarta, 2010, hlm. 169.

16 Widita Kurniasari, “Analisis Neraca Kasus Pemberian Dana Talangan (Bailout) Bank Century”, Jurnal Infestasi, Vol. 8, No. 1, 2012, hlm. 97-106.

${ }^{17}$ Qiping Tang, "The US Financial Regulatory Reform, Causes of Financial Crisis and Its Enlightenment on China”, Frontiers of Law in China Vol. 6, No. 4, 2011, hlm. 553-576.
} 
Salah satu alasan dikeluarkan Perpu Nomor 1 Tahun 2020 tercantum dalam diktum menimbang yaitu diakibatkan oleh penyebaran Corona Virus Disease 2019 (COVID-19) yang dinyatakan oleh Organisasi Kesehatan Dunia (World Health Organization) sebagai pandemi pada sebagian besar negara-negara di seluruh dunia termasuk di Indonesia. Apabila diktum tersebut sudah tepat, maka kasus Covid-19 dapat dikategorikan sebagai bencana alam sebagaimana yang tercantum dalam penjelasan pada Pasal 2 ayat (2) Undang-Undang Nomor 31 Tahun 1999 juncto Undang-Undang Nomor 20 Tahun 2001. Oleh karena itulah, apabila terjadi tindakan merugikan perekomonian negara atau memperkaya orang lain atau korporasi maka pejabat tersebut layak dituntut dengan pidana mati, bukan justru malah diberikan kekebalan hukum. Meskipun dalam hukum administrasi negara dikenal dengan tindakan diskresi, namun tindakan tersebut harus memenuhi syarat-syarat yang bersifat kumulatif, yaitu:

a. bertujuan melancarkan penyelenggaraan pemerintahan;

b. bertujuan mengisi kekosongan hukum;

c. bertujuan memberikan kepastian hukum;

d. bertujuan mengatasi stagnasi pemerintahan dalam keadaan tertentu guna kemanfaatan dan kepentingan umum;

e. tidak bertentangan dengan ketentuan peraturan perundang-undangan;

f. sesuai dengan AUPB;

g. berdasarkan alasan-alasan yang objektif;

h. tidak menimbulkan Konflik Kepentingan; dan

i. dilakukan dengan iktikad baik.

Beradasarkan hal-hal tersebut di atas, alasan diterbitkannya Perpu Nomor 1 Tahun 2020 belum memenuhi sejumlah persyaratan untuk dikategorikan sebagai tindakan diskresi, karena tidak terjadi kekosongan hukum dimana regulasi yang mengatur terkait tindakan korupsi dalam kondisi bencana sudah diatur dalam Undang-Undang Nomor 31 Tahun 1999, selain itu Perpu Nomor 1 Tahun 2020 juga melahirkan ketidakpastian hukum terkait penanganan kasus korupsi dalam kondisi bencana. Konsepsi likuiditas yang didasarkan pada krisis moneter ketika menjadi sebuah alasan tersirat bahwa Pemerintah menyatakan Indonesia dalam 
posisi terjadi krisis moneter, maka selayaknya pelaku Tindak Pidana Korupsi harus dituntut hukuman mati bukan sebaliknya malah diciptakan pasal yang memberikan kekebalan hukum. Terlihat terdapat dua pasal yang bersifat kontradiktif yaitu antara Perpu Nomor 1 Tahun 2020 dan Undang-Undang Nomor Nomor 31 Tahun 1999 juncto Undang-Undang Nomor 20 Tahun 2001.

4. Pasal 19 Undang-Undang Nomor 30 Tahun 2014 tentang Administrasi Pemerintahan dan Pasal 1 ayat (3) Undang-Undang Nomor 5 Tahun 1986 juncto Undang-Undang Nomor 9 Tahun 2004 tentang Peradilan Tata Usaha Negara

Pasal 27 ayat (3) Perpu Nomor 1 Tahun 2020 menyatakan bahwa segala tindakan termasuk keputusan yang diambil berdasarkan Peraturan Pemerintah Pengganti Undang-Undang ini bukan merupakan objek gugatan yang dapat diajukan kepada peradilan tata usaha negara. Hal tersebut secara tidak langsung menyatakan bahwa segala tindakan Pejabat yang didasarkan oleh Perpu tidak boleh dilakukan koreksi oleh siapapun. Selain melanggar prinsip negara hukum rechstaat yang mana adanya Peradilan Administrasi untuk mengadili keputusan Pemerintah, ketentuan ini juga melanggar sejumlah pasal dalam undang-undang.

Berdasarkan pada Pasal 1 ayat (3) Undang-Undang Nomor 5 Tahun 1986 juncto Undang-Undang Nomor 9 Tahun 2004 tentang Peradilan Tata Usaha Negara disebutkan bahwa "Keputusan Tata Usaha Negara adalah suatu penetapan tertulis yang dikeluarkan oleh Badan atau Pejabat Tata Usaha Negara yang berisi tindakan hukum Tata Usaha Negara yang berdasarkan peraturan perundang-undangan yang berlaku, yang bersifat konkret, individual, dan final, yang menimbulkan akibat hukum bagi seseorang atau badan hukum perdata".

Bahkan dalam Pasal 19 Undang-Undang Administrasi Pemerintahan, bukan hanya "keputusan" semata yang bisa dijadikan objek sengketa di Peradilan Tata Usaha Negara, melainkan "tindakan" Pejabat Tata Usaha Negara juga bisa menjadi objek yang disengketakan. Oleh karena itulah terdapat hal yang kontradiktif terhadap ketentuan dalam undang-undang ini dengan Perpu Nomor 1 Tahun 2020. Memang pada Pasal 2 Undang-Undang Nomor 9 Tahun 2004 terdapat sejumlah Keputusan Pejabat TUN yang dikecualikan atau dalam artian tidak bisa dijadikan objek sengketa TUN, yaitu:

a) Keputusan Tata Usaha Negara yang merupakan perbuatan hukum perdata; 
b) Keputusan Tata Usaha Negara yang merupakan pengaturan yang bersifat umum;

c) Keputusan Tata Usaha Negara yang masih memerlukan persetujuan;

d) Keputusan Tata Usaha Negara yang dikeluarkan berdasarkan ketentuan Kitab Undang-Undang Hukum Pidana dan Kitab Undang-Undang Hukum Acara Pidana atau peraturan perundang-undangan lain yang bersifat hukum pidana;

e) Keputusan Tata Usaha Negara yang dikeluarkan atas dasar hasil pemeriksaan badan peradilan berdasarkan ketentuan peraturan perundang-undangan yang berlaku;

f) Keputusan Tata Usaha Negara mengenai tata usaha Tentara Nasional Indonesia;

g) Keputusan Komisi Pemilihan Umum baik di pusat maupun di daerah mengenai hasil pemilihan umum.

Akan tetapi peniadaan keputusan Pejabat TUN sebagaimana tersebut diatas dikecualikan atau tidak dimasukkan kedalam Keputusan TUN dikarenakan untuk menghilangkan potensi dualisme dalam penegakan hukum. Sebagai contoh Keputusan KPU, penyelesaian sengketanya terkait administrasi melalui Badan Pengawas Pemilu (Bawaslu) sementara itu terkait sengketa hasilnya ada di Mahkamah Konstitusi.

\section{Penutup}

Pasal 1 ayat (3) UUD NRI 1945 menyatakan bahwa Indonesia merupakan negara hukum, dalam artian segala tindakan negara haruslah didasarkan pada prinsip-prinsip negara hukum yang salah satunya adalah pembatasan kekuasaan, persamaan di depan hukum serta peradilan khusus di bidang administrasi. Hal tersebut kontradiktif apabila melihat sejumlah norma yang tercantum dalam Perpu Nomor 1 Tahun 2020 yang salah satu pasalnya adalah peniadaan sanksi pidana ataupun perdata bagi pejabat yang melakukan tindakan merugikan negara baik dalam bentuk memperkaya diri sendiri maupun korporasi.

Selain pemberian hak imunitas bagi pelaku tindak pidana korupsi, Perpu Nomor 1 Tahun 2020 juga memberi peluang untuk terjadinya pengulangan kasus likuiditas Bank yang terjadi pada era krisis ekonomi 1998 dan 2008. Padahal fenomena yang terjadi pada 2020 merupakan wabah pandemi Covid-19 bukan persoalan moneter, dan sebelum dikeluarkannya Perpu Nomor 1 Tahun 2020, Pemerintah Indonesia belum pernah secara resmi menetapkan Indonesia dalam 
kondisi krisis moneter meskipun dalam diktum menimbang disampaikan bahwa Perpu tersebut dilahirkan sebagai bentuk antisipasi efek wabah pandemi Covid-19 yang akan berdampak secara tidak langsung terhadap sektor fiskal dan moneter.

Selain itu, pemberian hak imunitas pada kondisi bencana nasional ataupun krisis moneter sangat kontradiktif dengan penjelasan Pasal 2 undang-undang tentang Pemberantasan Tindak Pidana Korupsi yang justru diperberat hukumannya yaitu pidana mati, bukan malah dilonggarkan serta diberikan hak imunitas. Banyaknya pasal didalam Perpu Nomor 1 Tahun 2020 yang bertentangan dengan UUD NRI 1945 maupun undang-undang akan menciptakan permasalahan didalam penegakan hukum, karena selain berpotensi menghadirkan ketidakpastian hukum karena pemberlakuan undang-undang yang dibatasi hingga selesainya wabah sangat absurd dan berpotensi menghadirkan penyimpangan juga berpotensi melahirkan tindakan koruptif yang dilindungi oleh peraturan perundang-undangan. Oleh karena itulah, Perpu Nomor 1 Tahun 2020 sebagai dasar hukum Pemerintah dalam menjalankan tugasnya untuk mengatasi wabah pandemi Covid-19 selayaknya ditinjau kembali baik melalui mekanisme executive review yaitu dengan Perpu baru untuk membatalkan Perpu yang lama, legislative review yaitu dengan menggunakan fungsi legislasi DPR untuk membuat undang-undang baru ataukah dengan mekanisme judicial review yaitu dengan mengajukan uji materi ke Mahkamah Konstitusi.

\section{Daftar Pustaka}

\section{Buku}

Ashiddiqie, Jimly, Konstitusi Dan Konstitusionalisme Indonesia, Konstitusi Press, Jakarta, 2005.

, Pokok-Pokok Hukum Tata Negara Indonesia Pasca Reformasi, PT Bhuana Ilmu Populer, Jakarta, 2007.

Hariyani, Iswi, Restrukturisasi Dan Penghapusan Kredit Macet, Kompas Gramedia, Jakarta, 2010.

Ibrahim, Johni, Teori Dan Metodologi Penelitian Hukum Normatif, Bayumedia Malang, Publishing, 2007.

\section{Jurnal}

Boulanger, Christian. "Constitutionalism in East Central Europe? The Case of Slovakia under Meciar," East European Quarterly, Vol. 33, No. 1, 1999. 
Greenfield, Kent. "The Unjustified Absence of Federal Fraud Protection in the Labor Market," Yale Law Journal, Vol. 107, No. 3, 1997.

Lu, Wenling, and David A. Whidbee, "US Bank Failure and Bailout during the Financial Crisis: Examining the Determinants of Regulatory Intervention Decisions," Journal of Financial Economic Policy, Vol. 8, No. 3, 2016.

Made Sugi Hartono, "Korupsi Kebijakan Oleh Pejabat Publik (Suatu Analisis Perspektif Kriminologi)," Jurnal Komunikasi Hukum (JKH), Vol. 2, No. 2, 2016.

Price, Zachary S. "Funding Restrictions and Separation of Powers," Vanderbilt Law Review, Vol. 71, No. 2, 2018.

Ridwan HR, Despan Heryansyah, dan Dian Kus Pratiwi, "Perluasan Kompetensi Absolut Pengadilan Tata Usaha Negara Dalam Undang-Undang Administrasi Pemerintahan," Jurnal Hukum Ius Quia Iustum, Vol. 25, No. 2, 2018.

Sarah, "Hegemoni Melalui Regulasi Virus Sharing Internasional: Studi Kasus Virus Flu Burung A (H5N1) Indonesia," Jurnal Penelitian Hukum De Jure, Vol. 19, No. 10, 2019.

Tang, Qiping, "The US Financial Regulatory Reform, Causes of Financial Crisis and Its Enlightenment on China," Frontiers of Law in China, Vol. 6, No. 4, 2011.

Thomsen, Frej Klem. "Concept, Principle, and Norm-Equality before the Law Reconsidered," Legal Theory, Vol. 24, No. 2, 2018.

Wallerstein, Immanuel, "Citizens All? Citizens Some! The Making of the Citizen," Comparative Studies in Society and History, Vol. 45, No. 04, 2003.

Widita Kurniasari, "Analisis Neraca Kasus Pemberian Dana Talangan (Bailout) Bank Century," Jurnal Infestasi, Vol. 8, No. 1, 2012.

Williams, Colin C., and Aysegul Kayaoglu, "The Coronavirus Pandemic and Europe's Undeclared Economy: Impacts And A Policy Proposal," South East European Journal of Economics and Business, Vol. 15, No. 1, 2020.

Zahermann Armandz Muabezi, “Negara Berdasarkan Hukum (Rechtsstaats) Bukan Kekuasaan (Machtsstaat)," Jurnal Hukum dan Peradilan, Vol. 6, No. 3, 2017

\section{Peraturan Perundang-undangan}

Undang-Undang Dasar Negara Republik Indonesia 1945

Peraturan Pemerintah Pengganti Undang-Undang Nomor 23 Tahun 1959 tentang Pencabutan Undang Undang No. 74 Tahun 1957 dan Menetapkan Keadaan Bahaya

Undang-Undang Nomor 5 Tahun 1986 tentang Peradilan Tata Usaha Negara 
Undang-Undang Nomor 31 Tahun 1999 tentang Pemberantasan Tindak Pidana Korupsi

Undang-Undang Nomor 24 Tahun 2007 tentang Penanggulangan Bencana

Undang-Undang Nomor 12 Tahun 2011 tentang Pembentukan Peraturan Perundang-undangan

Undang-Undang Nomor 30 Tahun 2014 tentang Administrasi Pemerintahan

Undang-Undang Nomor 6 Tahun 2018 tentang Kekarantinaan Kesehatan

Pemerintah Pengganti Undang-Undang (Perpu) Nomor 1 Tahun 2020 tentang Kebijakan Keuangan Negara dan Stabilitas Sistem Keuangan Untuk Penanganan Pandemi Corona Virus Disease 2019 (Covid-19) dan/atau Dalam Rangka Menghadapi Ancaman Yang Membahayakan Perekonomian Nasional dan/atau Stabilitas Sistem Keuangan 